$$
\text { 高出力・高ビーム品質グリーンレーザー }
$$

\title{
High Power and High Beam Quality Green Laser
}

\author{
中 村 強* \\ Tsuyoshi NAKAMURA
}

\begin{abstract}
Key Words: Green Laser, Second Harmonic Generation, High Power, High Beam Quality, Disk Laser, Wavelength Conversion, Copper Welding, Reflection Ratio
\end{abstract}

\section{1. 緒 言}

20 世紀最大の発明と言われるレーザーは1960 年に発明 されてから非常に広範な分野で使われるようになった。現 在も多くのレーザーが開発され、通信・測定・加工・娛楽 などで新たな用途が生み出されている。特に産業用途に関 しては非接触、局所加熱などの特徵を生かしレーザー発明 以前の従来工法ではなし得なかった高生産性、高精度加工 などを実現した。産業の製造工程で使用される主要な用途 は溶接や切断であるため、これまではより高速により厚物 の加工をするために高出力・高ビーム品質の開発に主眼が 置かれていた。レーザーが産業用の加工に使用され始めた 当初は高出力レーザーは $\mathrm{CO}_{2}$ レーザーのみであったがその

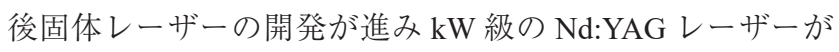
開発された。その後 2000 年以降に、高出力・高ビーム品質・ 高エネルギー変換効率・長寿命・小型・低価格のディスク レーザー ${ }^{1)}$ やファイバーレーザー ${ }^{2)}$ が開発・実用化され製 造工程における固体レーザーの使用比率と重要性が一変し た。高出力化により高速で深い溶接が可能になり、板金業 界、自動車業界、電気・電子業界を始幅広い産業分野で 使用されるようになった。しかしながら、レーザーは光で あるため照射対象物に対し反射と吸収の現象が生じる。一 部のエネルギーは加工対象（ワーク）に吸収され熱となり 加工に寄与するがそれ以外のエネルギーはワーク表面で反 射され加工に寄与しない。そのため、加工効率や加工状態 は対象ワークの物性に依存する。例えば銅の場合、反射率 は $10 \mu \mathrm{m}$ の波長で $98.8 \% 、 1 \mu \mathrm{m}$ で 98.5\%であるのに対して $0.5 \mu \mathrm{m}$ の波長では $60.0 \%$ である ${ }^{3)}$ 。近年自動車が内燃機関 エンジンから電動に置き換わる動きが加速し、銅の使用比 率が急速に高まり、銅の加工工程も増加している。このよ うな中で銅をレーザーで加工したいとの要望が高まってい る。しかしながら現行の高出力固体レーザーは波長が $1 \mu \mathrm{m}$ 前後で、銅に対する吸収率が非常に低い。そこで銅に対す る吸収率の良い短波長のレーザー開発が望まれていた。こ
のような要望に対応すべく、今般 TRUMPF は高出力グリー ンレーザーを開発した。本稿ではこの高出力・高ビーム品 質のグリーンレーザーについて解説する。

\section{2. レーザーによる銅の加工特性}

前述のように、銅の反射率は高出力が可能である $\mathrm{CO}_{2}$ レー ザーや固体レーザーの波長帯域 $10 \mu \mathrm{m} \sim 1 \mu \mathrm{m}$ では $98.5 \%$ 以上と非常に高い。一方、本稿で述べるグリーンレーザー の波長近傍である $0.5 \mu \mathrm{m}$ では $60.0 \%$ と低くなる。銅の分光 反射率を Fig. 1 に示す。本デー夕は銅を真空蒸着してつくっ た清浄な表面での反射特性であるためこの反射率は通常の 研磨面よりも高い。実際に加工に使用される銅はこれより も若干反射率が下がる。

$\mathrm{Yb}: \mathrm{YAG}$ レーザーの基本波である $1.03 \mu \mathrm{m}$ の波長 (以下基 本波という) とその第二高調波である $515 \mathrm{~nm}$ の波長 (以下 グリーンレーザーという) のレーザーによる銅の溶融状態 の違い4) を以下に示す。

2.1 同一パルス幅による溶融状態の違い

Fig. 2 にパルス幅 $5 \mathrm{~ms}$ の基本波（図中 IR：infrared と表

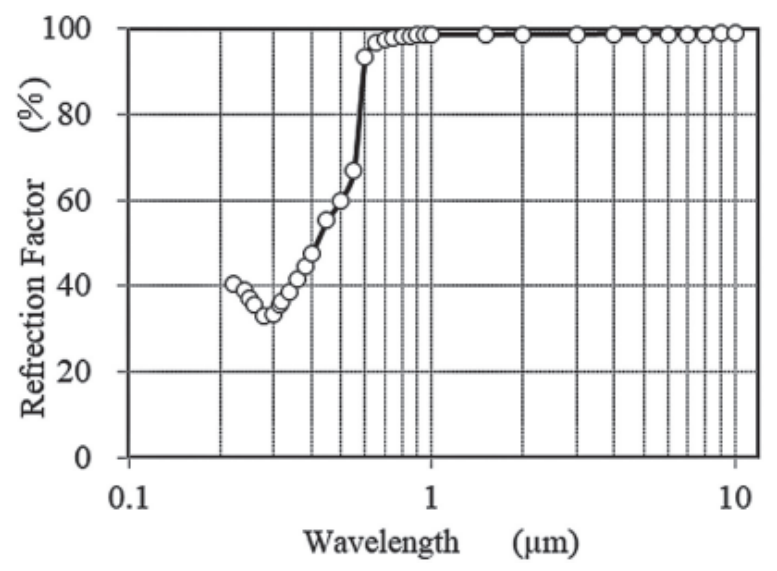

Fig. 1 Spectral reflection factor of copper.

*トルンプ株式会社 レーザー技術部（† 226-0006 神奈川県横浜市緑区白山 1-18-2）

Laser Engineering Department, TRUMPF CORPORATION (1-18-2, Hakusan, Midori-ku, Yokohama, Kanagawa, 226-0006, Japan) 


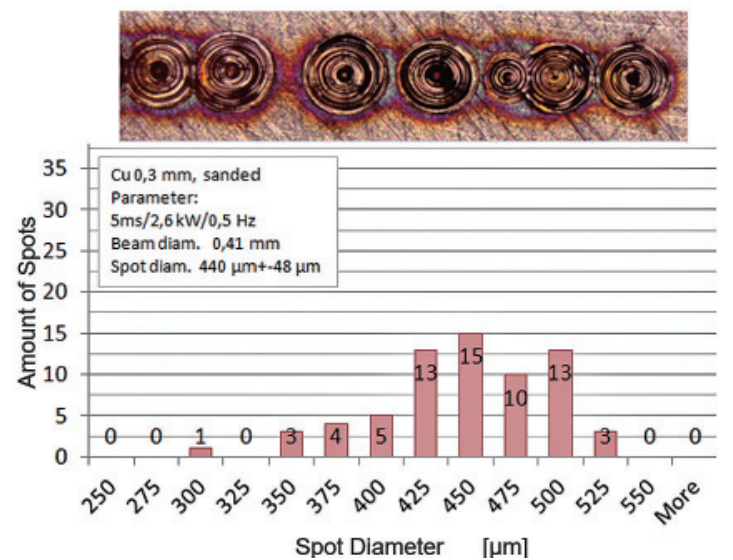

(a) IR

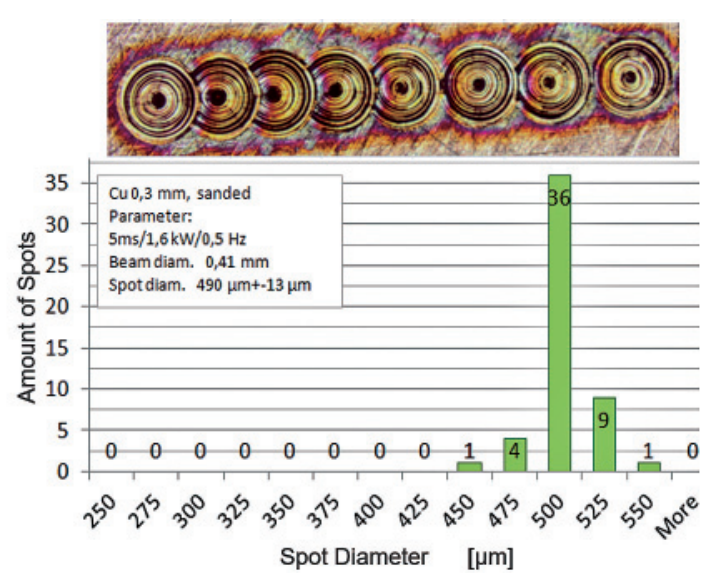

(b) Green

Fig. 2 Variation in spot diameter using (a) IR and (b) green laser.

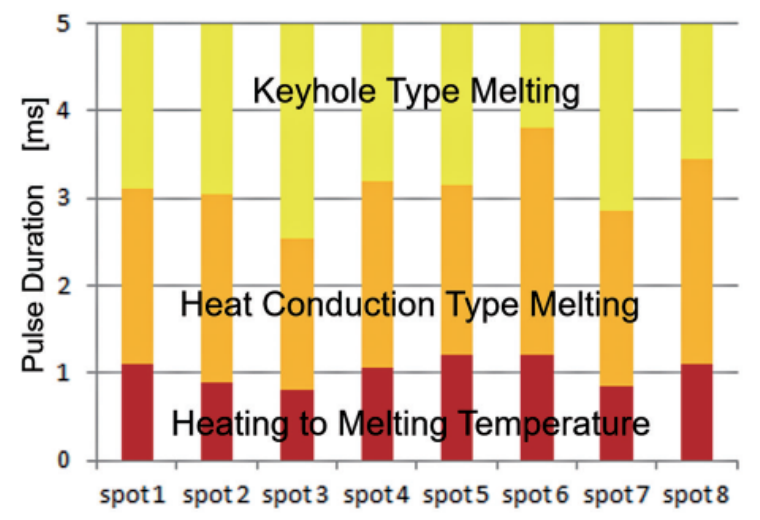

(a) IR

-Beam diameter $0.4 \mathrm{~mm}$

-Pulse duration $5 \mathrm{~ms}$

-Pulse power $2.6 \mathrm{~kW}$

-Welding depth $0.3 \mathrm{~mm}$

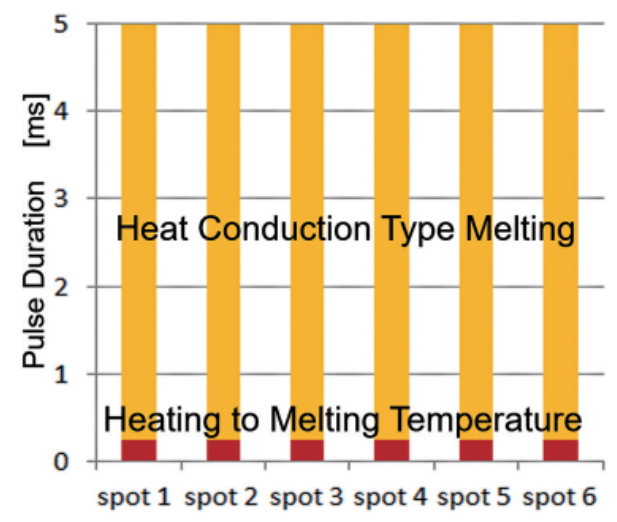

(b) Green Laser

-Beam diameter $0.4 \mathrm{~mm}$

-Pulse duration $5 \mathrm{~ms}$

-Pulse power $1.6 \mathrm{~kW}$

-Welding depth $0.3 \mathrm{~mm}$

Fig. 3 Difference of melting phase transformation in $5 \mathrm{~ms}$ using (a) IR and (b) green laser.

示）とグリーンレーザーを粗い表面状態の銅に数十回照射 したときの溶融状態の写真とその溶融径を測定した結果 のヒストグラムを示す。基本波では同一条件で照射したに もかかわらず溶融状態が大きくばらつくのに対しグリー ンレーザーではどの溶融状態も同一で再現性のよい溶融 となっている。この溶融径を測定した結果のヒストグラ ムから明らかなように基本波による溶融径は $300 \mu \mathrm{m}$ から $525 \mu \mathrm{m}$ まで幅広く分布しているのに対してグリーンレー ザーによる溶融径はほぼ $500 \mu \mathrm{m}$ に集中しておりばらつき が非常に小さく再現性の高いものになっている。一般的に 金属にレーザーが照射されると、金属表面でレーザーが吸 収され金属が加熱される。この加熱温度が融点に達すると 溶融が始まり、さらにレーザーのパワー密度が上昇すると 溶融金属の蒸発時に受ける反力によりキーホールが形成 される。Fig. 3 は $5 \mathrm{~ms}$ のパルス幅のレーザーを照射した 時の銅の加熱、溶融、キーホール形成への変化をそれぞ
れの形態へ何 $\mathrm{ms}$ で移行したかを調べたものである。基本 波、グリーンレーザーとも複数回実施した。基本波による 溶融は図に示すように加熱、溶融、キーホール形成と形態 が変化する時間がばらつくのに対してグリーンレーザー による溶接は加熱から溶融に関してほぼ同一の時間で形 態が変化している。また、基本波による溶融は短時間の熱 伝導型の溶融状態からすぐにキーホール型の溶融状態に 移行してしまう。熱伝導型の状態で留めておくことはで きず短時間でキーホール型に移行してしまうため、この キーホール型の溶融状態が $5 \mathrm{~ms}$ のうち何 $\mathrm{ms}$ であったか が溶融径や溶融深さを決定する要因となる。一方、グリー ンレーザーによる溶融は加熱からすぐに熱伝導型の溶融 に移行し、その後熱伝導型の状態が保持される。そのため 溶融深さや溶融径はこの熱伝導型の時間で決まり、また、 この熱伝導型の状態で留めることが可能であるため、溶融 深さのコントロールも可能となる。 


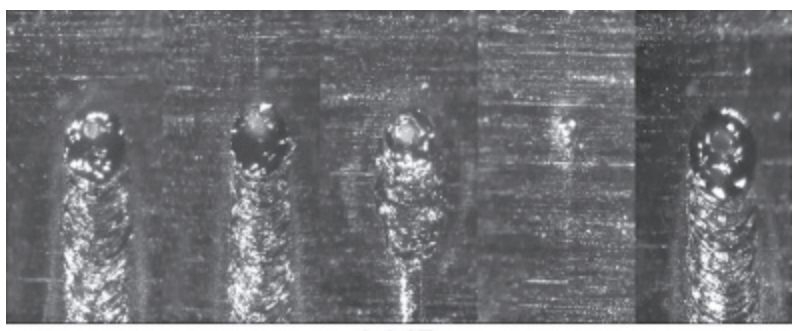

(a) IR

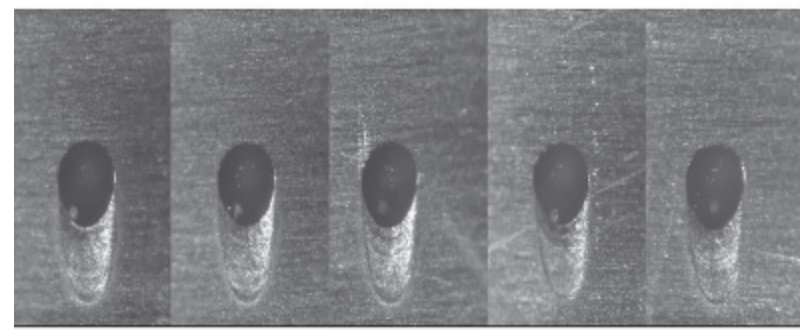

(b) Green

Fig. 4 Difference of copper melting condition with CW (a) IR and (b) green laser.

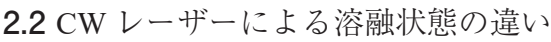

Fig. 4 に連続波 (Continuous Wave, CW) の基本波とグリー ンレーザーによる銅の溶融状態を示す。これはレーザー照 射開始から溶融が開始されるまでをそれぞれ 5 回繰り返し た写真である。前述した溶融のメカニズムにより、基本 波による溶融はレーザー照射から溶融開始までの時間にば らつきが生じるが、グリーンレーザーではほぼ同時に溶融 が開始されている。また、基本波による溶融はキーホール の形成が見られ、レーザー照射から溶融が開始されるまで に時間を要するにもかかわらず、一旦溶融が開始されると 短時間でキーホール状態にまで進むことがわかる。一方グ リーンレーザーによる溶融はレーザー開始後すぐに始ま り、熱伝導型を保っていることが分かる。

\section{3 銅の表面状態の差による溶融状態の違い}

Fig. 5 に異なる表面状態の銅の溶融状態を示す。表面状 態は（1）未処理 (2) 粗し（3）研磨（4）酸処理した 4 種類で ある。基本波による溶融は銅の表面状態に大きく依存し、 例えば、研磨状態のものでは溶融が開始されていない状態 にもかかわらず粗しおよび酸処理した表面のものは強く溶 融されておりスパッタの発生も確認される。一方、グリー ンレーザーによる溶融はいずれの表面状態でも同一の溶融 状態となっている。通常、レーザーの反射率は金属表面状 態によって変わり、研磨面のような清浄な表面程反射率が 高く、粗い表面程反射率が低く吸収率が高い。前述のよう に銅に対する基本波の吸収率は低く、未処理表面の銅に対 しては 5\% 程度と思わる。表面を粗し・酸処理あるいは研 磨した面では未処理表面より吸収率が数％増減する。この ような数\%の変動でも研磨面と粗し表面では吸収率は数倍 の相違となり溶融状態に大きな影響が生じる。一方グリー ンレーザーは未処理表面の銅に対して $40 \%$ 程度の吸収率で

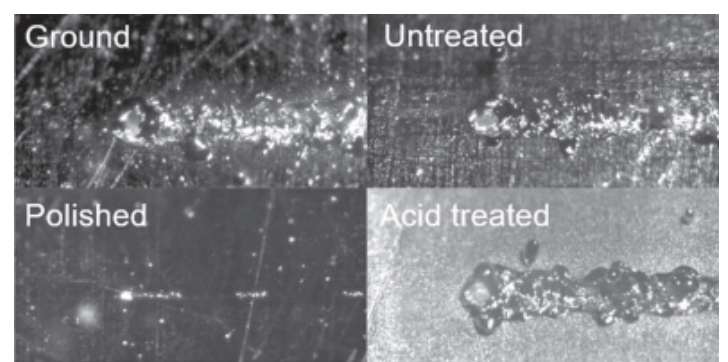

(a) IR

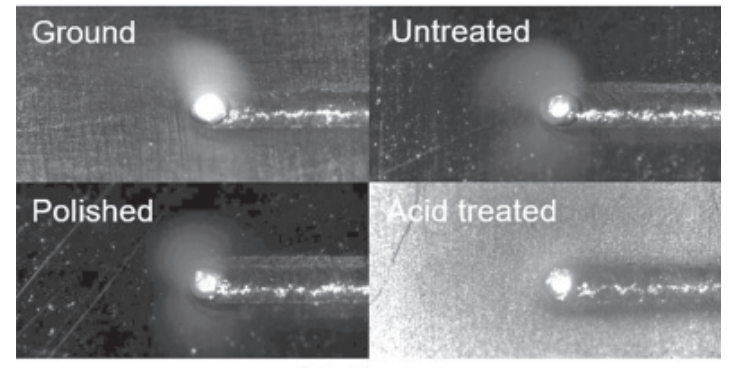

(b) Green

Fig. 5 Welding condition differences between CW (a) IR and (b) green laser with different surface condition.

あるため、表面処理による数％の増減は変動率としては小 さく溶融にほとんど影響しない。

2.4 基本波とグリーンレーザーの銅溶融メカニズム

前述のように基本波の銅の反射率は $98.5 \%$ 、すなわち吸 収率は $1.5 \%$ 、一方のグリーンレーザーの反射率は $60 \%$ 、 すなわち吸収率は $40 \%$ である。また、この吸収率は表面 温度や銅の形態によっても変わる。表面温度が上昇すると ともに吸収率も徐々に上昇する。その後温度が融点に達し 形態が固体から液体になるときに吸収率がステップ上に 上昇する。さらにこの溶融が熱伝導型からキーホール型 に移行しキーホールが形成され始めると吸収率がさらに 上昇し深いキーホールが形成されると最終的に $90 \%$ 以上 まで吸収率が上昇する5 。この状態になると基本波でもグ リーン波長でも同程度の吸収率になる。この変化の状態を Fig. 6 に示す。すなわち基本波による銅の溶接は室温の非 常に吸収率の低い状態から液体、さらにキーホールが形成 されるにしたがって急激に吸収率が上昇し、この吸収率 の上昇をコントロールできず溶接が不安定になる。また 銅が固体状態のとき吸収率が低いため溶融させるために パワー密度の高いレーザーを照射する必要があるが一旦 溶融を開始するとこのパワー密度では一瞬のうちにキー ホール溶接に移行してしまう。すなわち、基本波による銅 の溶接は熱伝導型の溶接状態を保持できず、固体の加熱状 態かキーホール型溶融のいずれかの状態になってしまう。 以上のように基本波による銅溶接の不安定はこのような 最終的には $20 \sim 30$ 倍にもなる吸収率の変化に大きさに 因るものと考えられる。一方、グリーン波長の吸収率も同 様に変化するが、固体の室温状態ですでに吸収率が $40 \%$ 


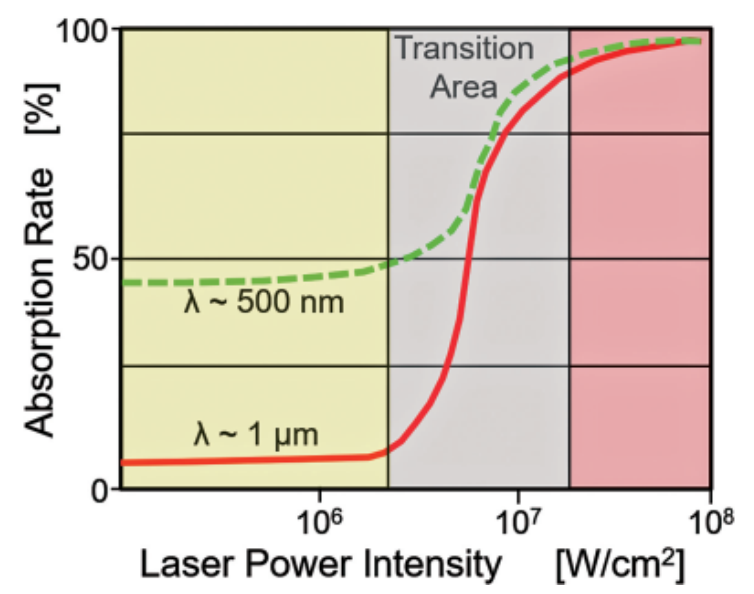

Fig. 6 Change of absorption rate with laser power intensity.

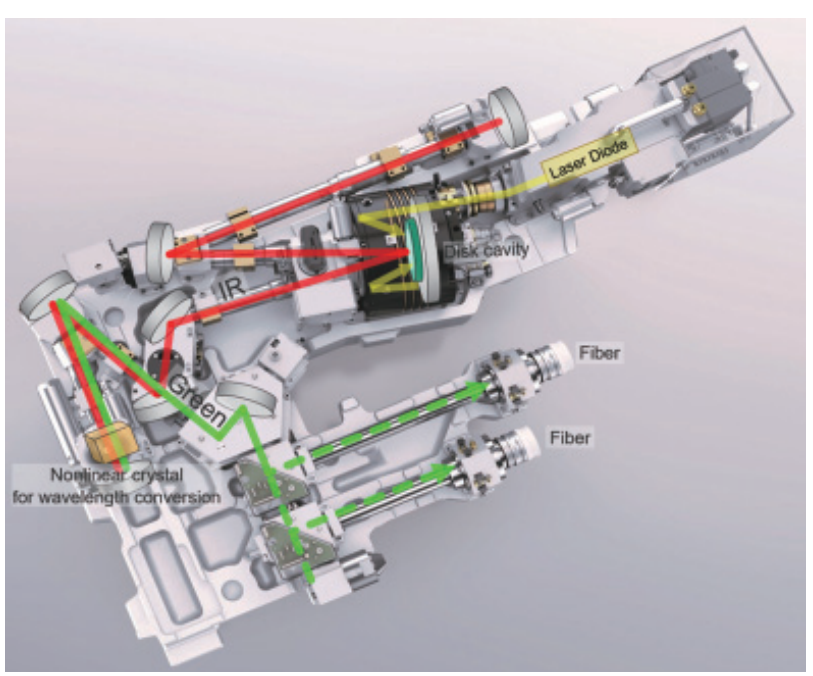

Fig. 7 Green laser oscillator.

程度であるためその後の溶融状態への吸収率の変化や深 いキーホール状態での吸収率の上昇は変化率としては大 きくなくせいぜい倍程度となる。この变化率の大きさの差 が基本波長とグリーン波長による銅の溶接のしやすさの 差になっていると考えられる。

\section{3. グリーンレーザー発振器}

TRUMPF のグリーンレーザーは波長変換方式を用い、 Disk レーザーの基本波 $(1030 \mathrm{~nm})$ から第二高調波 (515 $\mathrm{nm}$ ) を発生させる。Fig. 7 に発振器の基本構造を示す。 Disk レーザーの共振器内に波長変換用の非線形結晶を配置 し、基本波がこの結晶を通過することで第二高調波である $515 \mathrm{~nm}$ の波長のレーザーが生成される。その後 $1030 \mathrm{~nm}$ と $515 \mathrm{~nm}$ のレーザーが共振器内で共存するが、共振器内に $515 \mathrm{~nm}$ の光のみを透過する膜をコーティングした折り返し ミラーを設けることで、この折り返しミラーから $515 \mathrm{~nm}$ の光のみを取り出す。共振器内で波長変換を行うことで变 換効率は高い。

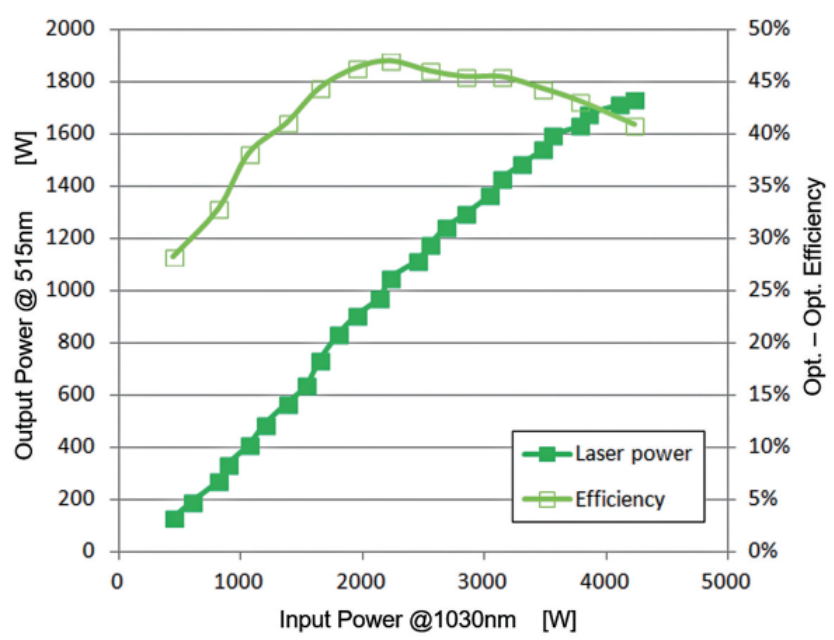

Fig. 8 Input-output characteristics of $1 \mathrm{~kW} \mathrm{CW}$ green laser.

Fig. 8 に $1 \mathrm{~kW}$ のグリーンレーザーの変換前の基本波の 出力と変換により生成される第二高調波の出力の関係を示 す。図から分かるようにグリーンレーザー $1 \mathrm{~kW}$ 発振時の 基本波から第二高調波への光 - 光変換効率は約 $47 \%$ であ る。このグリーンレーザーは Disk レーザーの基本波を波長 変換し生成しているため、基本的には基本波の特徵を有し ており、高出力にもかかわらず高ビーム品質を維持してい る。TRUMPF はパルス発振と連続発振の $1 \mathrm{~kW}$ および $2 \mathrm{~kW}$ のグリーンレーザーを有している。Table 1 にTRUMPF の グリーンレーザー発振器の仕様を示す。平均出力 $400 \mathrm{~W}$ 、 ピーク出力 $4 \mathrm{~kW}$ のパルスレーザは $\mathrm{BPP}=4 \mathrm{~mm} \cdot \mathrm{mrad}$ でコ ア径 $100 \mu \mathrm{m}$ のファイバーに導入可能、出力 $1 \mathrm{~kW}$ の CWレー ザーは $\mathrm{BPP}=2 \mathrm{~mm} \cdot \mathrm{mrad}$ と $\mathrm{BPP}=4 \mathrm{~mm} \cdot \mathrm{mrad} の 2$ 機種でそ れぞれ $50 \mu \mathrm{m}$ と $100 \mu \mathrm{m}$ のコア径のファイバーに導入可能、 出力 $2 \mathrm{~kW}$ の $\mathrm{CW} レ ー サ ゙ ー は ~ B P P=6 \mathrm{~mm} \cdot \mathrm{mrad}$ でコア径 150 $\mu \mathrm{m}$ のファイバーに導入可能である。また、デイスクレー ザーは発振器から出射されたレーザーをファイバーまで空 間伝送させファイバーのコア径以下に集光しファイバーに 導入する。このように空間を伝送させるため、折り返しミ ラーを複数設置することでビーム品質を維持したまま複数 光路のファイバーに導入可能である。現在、標準で 2 光路 仕様である。

\section{4. グリーンレーザーによる銅溶接への適用}

グリーンレーザーによる銅溶接の特徵は前述のように再 現性が高いことと熱伝導型溶接により精密な溶接深さのコ ントロールが可能なことである。この特徵を生かしたアプ リケーションの一例として銅薄板のボンディングがある。 セラミックス基板上にボンディング層として $0.15 \mathrm{~mm}$ 厚の 銅コーティングを施しその上に $0.3 \mathrm{~mm}$ 厚の銅板を溶接す るのにグリーンレーザーを用い、0.3 mm 厚の銅板を貫通 溶融後 $0.15 \mathrm{~mm}$ 厚の銅コーティング層の中間で溶接を止め る。このような浅い溶接の深さ制御は基本波では不可能で 


\section{スマートプロセス学会誌 第 9 巻 第 2 号 (2020 年 3 月)}

Table 1 Specification of TRUMPF green laser.

\begin{tabular}{|l|c|c|c|c|}
\hline & TruDisk Pulse 421 & TruDisk 1020 & TruDisk 1021 & TruDisk 2021 \\
\hline Pulse peak power & $4 \mathrm{~kW}$ & $1 \mathrm{~kW}$ & $1 \mathrm{~kW}$ & $2 \mathrm{~kW}$ \\
\hline Average Power & $400 \mathrm{~W}$ & $1000 \mathrm{~W}$ & $1000 \mathrm{~W}$ & $2000 \mathrm{~W}$ \\
\hline Wavelength & $515 \mathrm{~nm}$ & $515 \mathrm{~nm}$ & $515 \mathrm{~nm}$ & $515 \mathrm{~nm}$ \\
\hline Pulse duration & $0.3 \ldots 50 \mathrm{~ms}$ & $\mathrm{cW}$ & $\mathrm{cW}$ & $\mathrm{cW}$ \\
\hline Max. pulse energy & $40 \mathrm{~J}$ & --- & --- & -- \\
\hline Min. fiber core diameter & $\geq 100 \mu \mathrm{m}$ & $\geq 50 \mu \mathrm{m}$ & $\geq 100 \mu \mathrm{m}$ & $\geq 150 \mu \mathrm{m}$ \\
\hline Fiber cable length & $10,20 \mathrm{~m}$ & $10,20 \mathrm{~m}$ & $20 \mathrm{~m}$ & $10,20 \mathrm{~m}$ \\
\hline Number of outputs & $\mathrm{max} .2$ & $\mathrm{max} .2$ & $\mathrm{max} .2$ & $\mathrm{max} .2$ \\
\hline Beam Parameter Product & $4 \mathrm{~mm} \cdot \mathrm{mrad}$ & $2 \mathrm{~mm} \cdot \mathrm{mrad}$ & $4 \mathrm{~mm} \cdot \mathrm{mrad}$ & $6 \mathrm{~mm} \cdot \mathrm{mrad}$ \\
\hline
\end{tabular}
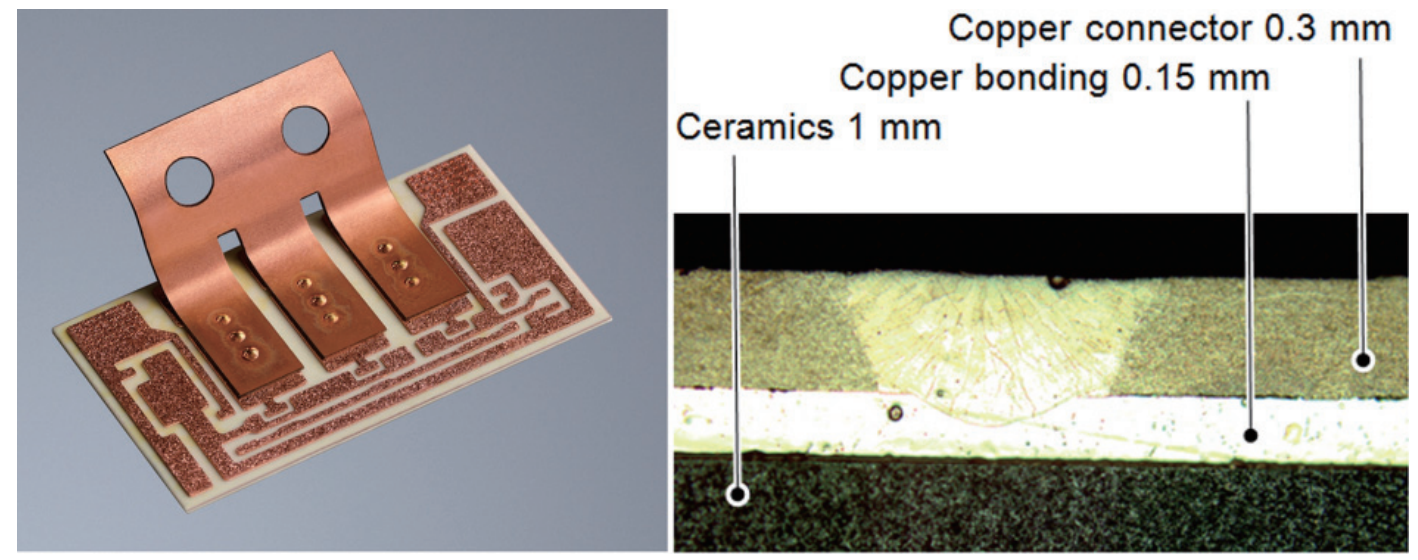

Fig. 9 Welding of copper bonding layer with green laser.
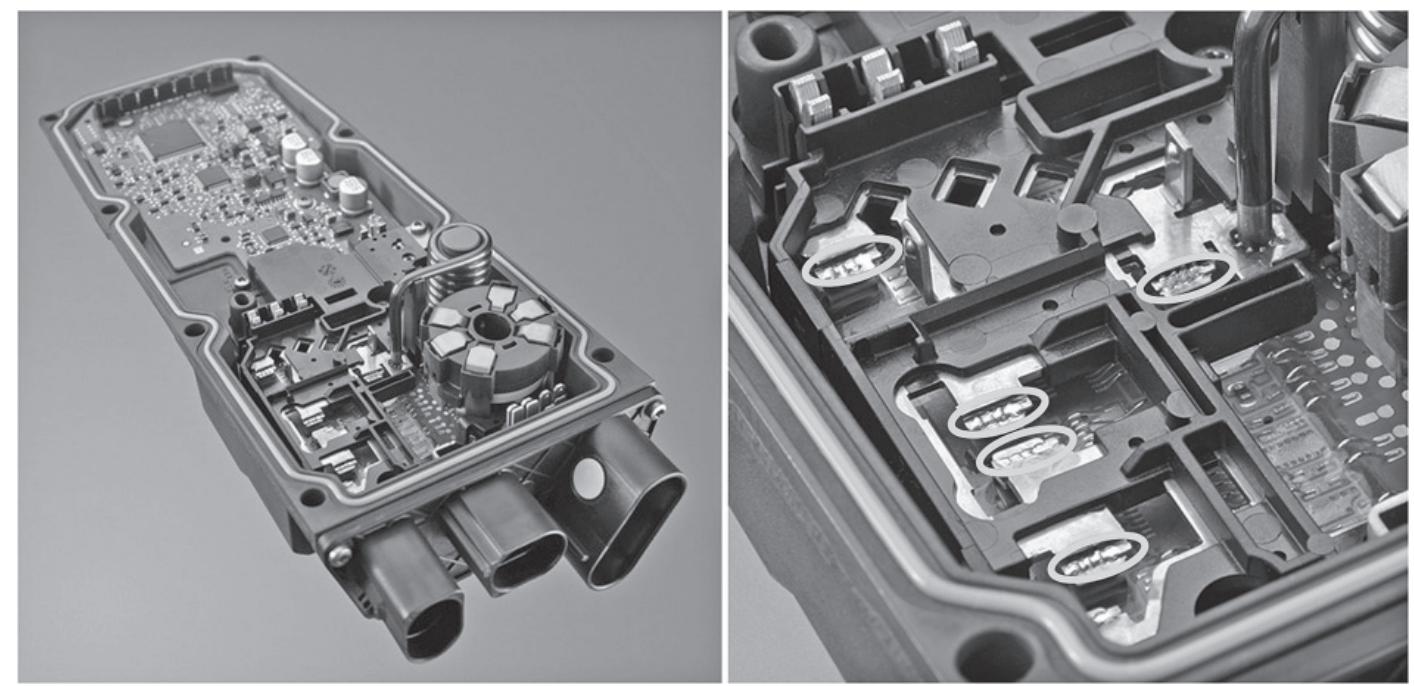

Fig. 10 Welding of copper terminal with green laser.

あり、銅に対して吸収率の高い短波長でのみ可能となる。

Fig. 9 に $0.15 \mathrm{~mm}$ 厚のコーティング層の中間で溶接を止め た時の外観と断面の写真を示す。

また、グリーンレーザーは銅に対して吸収率が高く反射 光が少ないため、反射光による周囲への影響が少ない。こ
の特性を生かし、Fig. 10 のような樹脂に囲まれた位置にあ る端子の溶接が可能となる。基本波による同様の溶接では 溶接部からの反射光により端子周囲の樹脂に焼けや溶けが 生じてしまうが、グリーンレーザーはこのような周囲のダ メージがないため、直接銅端子の溶接が可能になる。画像 
認識により端子の溶接位置を特定することで自動化を図る ことも可能である。

\section{5. 結 言}

以上述べてきたようにグリーンレーザーは銅に対して吸 収率が高いため、再現性が良く安定した加工ができ、熱伝 導型溶接による精密な溶融深さ制御が可能という様々な加 工上の利点を有する。今後車の電動化や情報社会の高度化 により電気を流し駆動するデバイスが増え、銅の加工需要 が格段に増える。このような加工に対して高品質な銅の加 工ができるグリーンレーザーは加工ッールとして重要性が 高まっていくものと思われる。また、基本構造がディスク レーザーで波長変換によりグリーンレーザーを生成する方 式は堅牢性、高出力、高ビーム品質など多くの利点を有し、 レーザーの自動化への高い適用性とあいまって今後多くの
量産ラインへの導入が期待される。

\section{参考文献}

1) A. Giesen, H. HiigeP, A. Voss, K. Wittig, U. Brauch, H. Opower: "Scalable concept for diode-pumped high-power solid-state lasers", Appl. Phys. B, 58 (1994), 365.

2) H. Po, J. Cao, B. Laliberte, R. Minns, R. Robinson, B. Rockney, R. Tricca, and Y. Zhang: Electron. Lett. 17 (1993), 1500.

3）国立天文台編：“理科年表”, 丸善, (2007), 445.

4) S. Engler, R. Ramsayer, R. Poprawe: "Process Studies on Laser Welding of Copper with Brilliant Green and Infrared Lasers". Physics Procedia 12 (2011), 339-346.

5）片山聖二：“レーザ溶接”，溶接学会誌， 78-2 (2009), 40-54.

\section{代表者メールアドレス}

中村 強 tsuyoshi.nakamura@trumpf.com 